\title{
The Draw-a-Family Picture Test (DAFPT): A New Projective Test for Children
}

\author{
Manuela Policarpio-Gutierrez \\ Nueva Ecija University of Science and Technology, Cabanatuan City, Philippines \\ Email: subiagener@yahoo.com
}

How to cite this paper: Policarpio-Gutierrez, M. (2018) The Draw-a-Family Picture Test (DAFPT): A New Projective Test for Children. Open Journal of Social Sciences, 6, 171-178.

https://doi.org/10.4236/jss.2018.68013

Received: August 6, 2018

Accepted: August 20, 2018

Published: August 23, 2018

Copyright (c) 2018 by author and Scientific Research Publishing Inc. This work is licensed under the Creative Commons Attribution International License (CC BY 4.0).

http://creativecommons.org/licenses/by/4.0/

(c) (i) Open Access

\begin{abstract}
The Draw-a-Family-Picture-Test (DAFPT) is a new projective test instrument developed to facilitate understanding of children. It comes with a guide for administration and interpretation. Evaluation of the test revealed that it is generally very fit for determining children's attitude, fears, needs, maturity level, stressors, gender tendencies and self-perception in relation to their family and significant others. Wide use of the instrument is therefore encouraged. Nonetheless, as the researcher believes that perfection can only be attained through time and modifications, it is suggested that this test be subjected for further study and necessary improvement if ever.
\end{abstract}

\section{Keywords}

Understanding Children, Children Attitude, Child Behavior, Meanings of Drawing

\section{Introduction}

"The children are our future, teach them well and let them lead the way. Show them all the beauty they possess inside. Give them a sense of pride. Let the children's laughter." [1] ... so the song goes.

Mandela said that the true character of the society is revealed on how it treats its children [2]. This further affirms the role that children play in the society and how important it is for the people to treat and raise them well. Sigmund Freud's Psycho analytic theory holds that most human suffering is determined during childhood development [3]; Erik Erikson's Psychosocial Theory holds that trusts and mistrust, initiative and guilt, industry and inferiority all develop during childhood [4] and Carl Jung agreed with Freud that a person's past and child- 
hood experiences determine their future behavior. However, he also believed that children are also shaped by their future aspirations. Jung's analytical theory holds that feelings of alienation or abandonment contribute to the development of the child's archetype in such that the "poor me" syndrome develops into regressive longing for dependence while the opposite develops into the positive side [5]. Based on the foregoing, there is no question that the child's early experiences define the future of the world. It is therefore necessary to help them be the kind of people the future needs. Helping them and facilitating their adjustment will be easy with the aid of a projective tool, because the innocent child will not come running to the experts and say he needs help. It is therefore necessary to find a tool that would help us see through the child. A number of instruments had already been developed years ago, with the aim of projecting what's in the mind of the child. There is the Rorschach by Herman Rorschach (1921), the Incomplete Sentence Blank (ISB) by Julian Rotter, the draw a person test (DAPT) by Florence Goodenough (1926), and the Bender-Gestalt (BGT) by Lauretta Bender (1938). As these tests project different information, it would be costly to use them all. So, I developed the DAFPT, had it evaluated by experts, and sought for its publication for wider usage and improvement.

\section{Methodology}

This study utilized the developmental research design. According to [6] as cited in [7] "developmental research is a systematic study of designing, developing, and evaluating instructional programs, processes, and products that must meet criteria of internal consistency and effectiveness". "The author in [6] added that it is particularly important in the field of instructional technology wherein the product development process is analyzed and described, and the final product is evaluated".

In this study, the DAFPT was the new product developed, analyzed and described. The participants were 15 purposively chosen children on the basis of their age, sex, and overall family condition. All of them were children with ages ranging from 5 to 10. Eight of them were girls and seven were boys. All of them were from the same income bracket but five were from family with extended members, five were had nannies and five were with basic family members only. After securing the informed consent of the parents, the children were given paper and pencil and asked to draw their family picture according to standard instruction, after which, their drawings were interpreted based on the principles of Draw a Person Test's [8] sequence and gender factors, Bender-Gestalt Test's [9] Placement and rotation factors. The interpreted results were then subjected to the judgment of five (5) expert users of DPT \& BGT. The experts were asked to rate the fitness of the DAFPT in measuring attitude towards family members, maturity level, and other tendencies.

The responses were rated using the following scale: 


\begin{tabular}{|c|c|c|}
\hline 4.20 to $5: 00$ & Very fit & The tool is very fit for measuring what it intends to measure \\
\hline 3.40 to 4.19 & Fit & The tool is fit for measuring what it intends to measure \\
\hline 2.60 to 3.39 & Moderately fit & The tool is moderately fit for measuring what it intends to measure \\
\hline 1.80 to 2.59 & Unfit & The tool is unfit for measuring what it intends to measure \\
\hline 1.00 to 1.79 & Very unfit & The tool is not fit at all for measuring what it intends to measure \\
\hline
\end{tabular}

The researcher also validated the interpretation of the drawing with the observation of children's parents and by asking the parents to rate also the fitness of the DAFPT.

\section{Results and Discussion}

\subsection{Conceptualization and Development of the Draw-a-Family-Picture-Test (The DAFPT)}

The DAFPT was conceptualized out of need for a single test that would give varied pieces of information that are usually given by a number of test, which can be costly. It was developed based on the principles of projective testing and anchored on the principles of projective techniques which are already tried and tested. It applied the gender and sequence factors of the Draw a Person Test, the maturity level factor of Goodenough Intelligence Test for children [8] and the placement and rotation factors of the Bender Gestalt Test.

The test result revealed that girls generally had lesser test anxiety than did boys; both boys and girls tend to place themselves near the person they were more emotionally attached with. There were those who placed themselves closer to the nanny or the granny. There was also one boy aged 5 who drew himself tinier than anybody else in the picture and farther away from the women with a baby bump in the picture, evidently his mother. It turned out that the boy was feeling insecure for the coming of a new baby and had been showing signs of regression. There were also drawing which suggested bullying of the respondent by other member of the family. Indeed, results were interesting and provided useful information for the counselor or the teacher to come in to the picture and help facilitate the children's adjustment.

\subsection{Test Description}

The DAFPT is an individual projective test that reveals to trained interpreter a child's attitude towards member of his family and his extended family members. It can somehow reveal how the child sees himself in relation to his home which serves as his immediate environment. It would show his emotions, family stressors and other sources of conflicts as far as family is concerned. It can be used as an important tool in counseling children to ensure their adjustment at home and in school.

I first tried the test among my children and among the children of couples known to me, with ages ranging from five to ten. The results were remarkably consistent with the parents and the teacher's observation of their children. Next, 
I tested its validity against the DAPT's sequence and gender factors; BGT's placement and rotation factors and Goodenough's intellectual maturity factor. Based on the evaluation and observation of my colleagues in the field of projective testing, there is enough reason to claim that DAFPT is surely a valid test.

\subsection{Administration of the Test}

DAFPT is an individual test and it is a must that the task be administered one-on-one with the subject. Result of the test may yield other information with the application of the interpreter's acquired knowledge in Psychometrics. It is therefore necessary that, as much as possible, an expert in the field of psychometrics make the necessary interpretation. Validation of the child's work against his/her responses in the follow-up questions is also necessary to avoid errors in interpretations.

In administering the test, it is likewise necessary to take note of the following;

1) Preparation of the Subject. The subject does not need any preparation beyond that of being rested and relaxed before taking the test. This is necessary to avoid test anxiety and to ensure that the subject is physically prepared for the task. The air of friendliness imparted by the test administrator is also an important concern to consider; hence it is of equal importance that the examiner also prepares self for the activity. His/her preparedness also encourage preparedness of the examinee.

2) Materials Needed. Materials needed in the administration of the test are pencils and white bond papers, a reasonably spacious room and a table with a chair that suits the subject's height and weight. A floor mat may also be needed for children who prefer to draw on the floor or a low-rise table for those who prefer to draw sitting on their legs or on the floor.

3) Condition Required. A friendly or a casual atmosphere and a well-lighted and moderately ventilated room that is free from noise so that the child can freely think and work, are an essential requirement in administering the test. This is to rule-out physical strain that may affect the results of the task. The room, however, should be free of family portraits or picture that may pose as a model and give idea of a family picture to the child. The child should draw on his own and, in his preference, and not based on models.

4) Test Administration. In administration the test, instruction is given step by step, with the examiner taking down notes of the child's behavior while working. If the child can draw, he/she should draw by himself or by herself. If the child cannot draw for physical or developmental reason, the examiner may draw for him/her but should constantly ask how the child would want each member of the family be drawn or where in the paper would he/she want the member and himself be placed.

The administration process should be spontaneous; so, enforcement by suggesting what and who to place and draw where must therefore be avoided. When the child is not ready as indicated by non-cooperation, the task should be taken aside for the moment until trust and rapport (in the case of absence of rapport) 
is eventually established or until the child is again ready to continue the task (it should always be remembered that the child's patience and tolerance is typically shorter).

Below are specific instructions by each stage of test administration. Nonetheless, the examiner can alter or modify his/her questions to suit with the child's mood. However, consideration should be taken not to force the child to respond to the task.

Stage 1. Explain to the child that he/she will be asked to draw a picture of their family.

Stage 2. If the child could not begin, encourage him/her by asking "who would you like to draw first?" After the child responded, say "okay then, draw him/her." After the first person is drawn, instruct the child to draw the rest of the members of the family. Confirm by asking if he/she is in the drawing with other family members. If he/she was not there, ask, "By whose side do you want to place yourself?" and let the child redraw placing himself or herself in the position he/she wants to be in. Then, ask if the child is satisfied with the arrangement. Let him/herre-draw or re-arrange the people in the drawing if necessary, then ask him/her to name the people in the drawing.

Stage 3. Proceed to this stage only after stage 2 is completely done. This stage includes asking the child the following questions: "who among the people in the picture are you most fond of... or least fond of" Why, or why not fond of?" "Say something about each of the people in the picture."

It is also advantageous to raise as many questions as you may find necessary to ask based on the child's responses. Always look for clues but be sensitive enough not to force the child to answer.

\subsection{Interpreting Result}

Meanings can be obtained outright from this test, and even during the administration process, if the examiner is knowledgeable of the basics of BGT, ISB and DAP. It is therefore recommended that the one who administers it must also have knowledge of the said tests, or must first be trained to interpret the test. Likewise, it is suggested that the examiner also be the interpreter and that he/she must have a clear memory to take "mental note", (without writing down) of important observations about the child's behavior during the test. This is necessary because children readily get apprehensive when they notice that they are being observed and that their behaviors are being noted.

1) Position of the first drawing. This should be interpreted in accordance to BGT's position of the first drawing. Further, if the person is drawn more to the left of the upper portion of the paper-the child tends to be insecure (particularly if the drawing is very small), dependent and fears contact with others. Otherwise, it means the opposite. If the first drawing is in middle, the child tends to be well adjusted; if in the lower portion of the paper, the child feels under pressure.

2) The person first drawn. The person first drawn is the person that registers most remarkably in the child's mind. This should be interpreted on the basis of 
the child's responses on questions regarding that person. A child who is well adjusted usually draws first the person he or she likes and most fond of.

3) The position of the examinee in the picture. Children (and even any more mature people) would want to be beside the people they like the most even in actual situations.

4) Distance of self from other persons in the picture. Distance means the average length of space that separates the child from the family members who are beside him/her in the picture. Is he/she remarkably far or close to the person to his left or to his right? Further from the average may mean alienation or aloofness; closer than the average may mean dependence or identification. The measure of what is average, however, depends upon the distance between other people in the drawing. This factor should be interpreted further with the aid of the child's responses to queries during the follow-up stage.

5) Other people in the drawing. Are there other people included in the drawing which are not supposed to be members of the family? What does the child say about them in the follow-up question? Why are they in the drawing when it was supposed to be a picture of the family? All these have meanings to the child. These surely signify something that registered in the child's young mind; otherwise they wouldn't be in the drawing. It is up to the interpreter and administrator to know through the art of questioning.

6) Sequence of the people in the drawing. Sequence of the people in the drawing tells about the degree of these people's appeal to the child or the degree of the child's affiliation with or alienation from them. An expert interpreter has a way of knowing.

7) Features of the people in the drawing. The details of the features of the people in the drawing i.e. the lines, the pressures, transparencies and the dimensions as well as the presence or absence of a feature all tell about the child. Too much pressure may mean pressure or stress, transparencies may mean poor judgement, absence of a feature may mean denial, stick lines may mean immaturity, and dimensional features may mean intellectual giftedness.

\subsection{Fitness of the DAFPT as a Projective Tool for Children}

The fitness level of DAFPT as a tool for revealing children's attitude towards family members, fears, needs, maturity level, stressors, gender tendencies and perception of self in relation to members of the family are apparently high and agreeable as revealed in Table 1.

Table 1 shows that with an average weighted means (awm) of 4.55 and 4.26, experts and parents believe that the DAFPT is a very fit tool in discovering the children's attitude towards family members. The tool is most particularly fit in revealing attitude of children towards father $(\mathrm{awm}=4.87)$ and mother $(\mathrm{awm}=$ $4.89)$, and in revealing their gender tendencies $(\mathrm{awm}=4.42)$, stressors $(\mathrm{awm}=$ $4.45)$ and fears $(\mathrm{awm}=4.30)$. Overall weighted average computed for the rating of both groups was 4.41, categorized also as very fit. Therefore, it can be concluded that the draw a family picture test based on the judgment of both groups 
Table 1. Summary of Fitness Rating of the DAFPT.

\begin{tabular}{|c|c|c|c|c|c|c|}
\hline $\begin{array}{l}\text { Fitness of DAFPT as a tool for projecting the } \\
\text { following information: }\end{array}$ & Experts & $\begin{array}{c}\text { Verbal } \\
\text { Description }\end{array}$ & Parents/Guardian & $\begin{array}{c}\text { Verbal } \\
\text { Description }\end{array}$ & $\begin{array}{c}\text { Average } \\
\text { Weighted Mean }\end{array}$ & $\begin{array}{c}\text { Verbal } \\
\text { Description }\end{array}$ \\
\hline 1) attitude towards mother & 4.94 & Very fit & 4.83 & Very fit & 4.89 & Very fit \\
\hline 2) Attitude towards father & 4.97 & Very fit & 4.77 & Very fit & 4.87 & Very fit \\
\hline 3) attitude towards siblings & 4.35 & Very fit & 4.25 & Very fit & 4.30 & Very fit \\
\hline 4) attitude towards extended family members & 4.20 & Very fit & 4.33 & Very fit & 4.27 & Very fit \\
\hline 5) fears & 4.56 & Very fit & 4.03 & Fit & 4.30 & Very fit \\
\hline 6) needs & 4.37 & Very fit & 4.05 & Fit & 4.21 & Very fit \\
\hline 7) maturity level & 4.34 & Very fit & 4.00 & Fit & 4.17 & Fit \\
\hline 8) stressors & 4.69 & Very fit & 4.21 & Very fit & 4.45 & Very fit \\
\hline 9) gender tendencies & 4.77 & Very fit & 4.06 & Fit & 4.42 & Very fit \\
\hline 10) perception of self & 4.31 & Very fit & 4.03 & Fit & 4.17 & Fit \\
\hline Overall Weighted Means & 4.55 & Very fit & 4.26 & Very fit & 4.41 & Very fit \\
\hline
\end{tabular}

Legend: 4.20 to 5:00, Very fit (VF); 3.40 to 4.19 , Fit (F); 2.60 to 3.39, Moderately Fit (MF); 1.80 to 2.59. Unfit (UF); and 1.00 to 1.79 , Very unfit (VUF).

of raters is a very fit tool for projecting or revealing the children's attitude towards their family members and also a very fit tool in revealing children's fears, needs, maturity level, stressors, gender tendencies and self-perception.

\section{Conclusions and Recommendations}

The DAFPT is a new individual projective test that reveals to trained interpreter a child's attitude towards member of his family and extended family members, the children's perception of self in relation to home and family, and their fears, needs, maturity level, stressors, and gender tendencies. It was rated as a very fit tool in projecting pieces of information that are necessary in helping the children to adjust better at home and in school, thereby enabling them to grow into well-adjusted and better individuals in the future.

Based on the conclusions it is therefore recommended that the DAFPT be shared among guidance counselor and psychometrician in other regions of the country or worldwide for wider utilization and validation since this study focused only on the DAFPT's applicability among local children. School Administrators should encourage its usage; other researchers may continuously improve it; and teachers should use it as a tool in understanding their pupils. It is also recommended that other psychometricians and the developer further study its applicability to older children and to children with disabilities.

\section{Acknowledgements}

My whole hearted gratitude goes to Dr. Gener S. Subia for his statistical assistance and unconditional support that I may finally come up with a sole-authored research for publishing in a refereed journal; to the experts in the past whose work provided me with the best material basis for the development of DAFPT; 
to the children and parents who served as my "try out participants" for their invaluable contribution in the development and validation of this work; to Dr. Arneil G. Gabriel and Dr. Bernardo A. Zabala for contaminating me with their "research virus" that I now want to submit more researches for publication; to my children and husband for the inspiration; and above all, to the Lord Almighty for his greatness and providence.

\section{Conflicts of Interest}

The author declares no conflicts of interest regarding the publication of this paper.

\section{References}

[1] Creed, L. and Houston, W. (1985) The Greatest Love of All. Arista Records, Sony Music Entertainment.

[2] Mandela, N. (2011) Nelson Mandela by Himself: The Authorized Book of Quotations. Pan Macmillan, p. 129.

[3] http://journalpsyche.org/the-freudian-theory-of-personality/downloaded

[4] Erikson, E.H. (1993) Childhood and Society. 2nd Edition, Norton, New York.

[5] Jung, C.G. (1921) Psychological Types. The Collected Works of CG Jung, 6.

[6] Richey, R. (1994) Developmental Research: The Definition and Scope. https://eric.ed.gov/?id=ED373753

[7] Subia, G.S. (2018) Think Like My Teacher (TLMT): A New Method in Assessing Millennial Learners. International Journal of Arts Humanities and Social Sciences, 3. www.ijahss.com

[8] Florence, L. Good Enough, 1886-1959. Child Development, 30, 305-306.

[9] Bender, L. (1938) A Visual-Motor Gestalt Test and Its Clinical Use. American Orthopsychiatric Association Research Monographs, 3. 